\title{
Prescribed Burning: Vegetative Forage Production, Cost, and Returns on Six Demonstration Burns in Utah.
}

\author{
MICHAEL H. RALPHS AND FRANK E. BUSBY
}

\begin{abstract}
Six demonstration burns were conducted between 1974 and i976 as part of the Utah Rangeland Development Program. Big sagebrush (Artemisia tridentata), the target species, was essentially eliminated on the areas that were burned. Five of the six burns were seeded, with predominately crested wheatgrass (Agropyron desertorum). Despite the severe drought only one seeding was considered a failure. Forage production increased several-fold above preburn production and is expected to continue to increase as the grass stands mature. An economic analysis of the 1974 burn showed an internal rate of return of $17 \%$. Great risks were associated with the use of fire. Extensive precautions were taken to minimize hazards but variable weather conditions in late summer greatly increased the chance of the fire escaping. Prescribed burning is inexpensive and effective in controlling big sagebrush when adequate safety precautions are taken.
\end{abstract}

Big sagebrush (Ártemisia tridentata) and juniper (Juniperous osteosperma, and $J$. monosperma) have been the object of many shrub control efforts in the Western United States. These species were present in the climax condition, but overgrazing reduced many desirable species and fire suppression prevented the natural check of sagebrush and juniper (Wright 1977). Sagebrush increased to where it totally dominated much of its original range (Blaisdell 1953; Cottam 1947; Tueller 1973), and juniper increased in density and encroached upon sagebrushbunchgrass communities (Blackburn and Tueller 1970; Plummer 1958; West et al. 1975). Grazing management alone will not check invasion of juniper nor appreciably improve deteriorated sagebrush and juniper communities (Blackburn and Tueller 1970; Burkhardt and Tisdale 1969).

The cost of traditional control methods of both sagebrush and juniper have increased tremendously. The effectiveness of cabling and chaining juniper have been questioned due to high cost and rapid reinvasion of young juniper trees (Aro 1971). Mechanical control of sagebrush is very expensive and is limited to level and relatively rock free sites. Pressure from environmental groups has limited the use of chemical control by the federal land management agencies. Fire is a natural part of the ecosystem and is very effective in controlling sagebrush and juniper. It is also relatively inexpensive (Nielsen and Hinkley

Authors are with the Saval Ranch. North Fork. Nevada, formerly Fxtension range technician. Utah State University: and associate professor, Range Science Dept., Utah Statc University. Logan. Ralphs was formerly Demonstration Ranch Coordinator and Busby was Executive Secretary of the Utah Rangeland Development Program. The Utah Ramgeland Development Program was funded by the Four Corners Regional Development Commission and Utah State University Extension Service

This report was published with the approval of the director, Utah Agricultural Exporiment Station as Journal Paper No. 2257

Manuscript received March 27, 1978.
1973 ) if proper safety precautions are taken and environmental conditions are planned for.

Multiple use benefits have been enhanced by fire (Wright 1974). Forage production has increased following burning in Sagebrush (Nielsen and Hinkley 1975; Uresk et al. 1976) and juniper (McCulloch 1969). Increased vigor of fire resistant grasses has been observed following burning (Daubenmire 1968). In some situations, water yields have been increased by the removal of sagebrush and juniper (Burkhardt and Tisdale 1969: Warskow 1977). With few exceptions, upland wildlife have an affinity for subclimax plant associations which fire is important in maintaining (Miller 1963).

Risks are incurred when using fire as a vegetation manipulation tool. Fire can readily escape and consume valuable forage, destroy fences and facilities, and leave the land owner liable for damages. (Pechanec et al. 1954). Accelerated erosion by both wind anc water can occur until vegetative cover is reestablished (Pechanec et al. 1954; Wri ut et al. 1976). If undesirable sprouting shrubs and annual grasses are abundant in the vegetative community, burning may enhance the competitive advantage of these unwanted species and further degrade the site (Pickford 19.32).

The key to effective burning is to select the climatic and environmental conditions in which fire will damage the target species without causing undue harm to the desirable species. Several articles have reviewed the effects of fire and burning conditions on a variety of the more important vegetative species (Blaisdell 1953; Britton and Ralphs 1978; Conrad and Poulton 1966; Wright 197i, 1972, 1977).

A series of demonstration burns was conducted throughout Utah in 1974 and i976 in conjunction with the Demonstration Ranch Project and the Utah Rangeland Develop nent Program. One objective of this program was to involve federal and state land management agencies in a coordinated planning effort and follow through with cooperative implementation of range improvements on private. state, and public lands. The Utah Division of Forestry and Fire Control. Bureau of Land Management (BLM). Forest Service, Soil Conservation Service (SCS). Agricultural Stabilization and Conservation Service (ASCS). Soil Conservation Districts, Utah Division of Wildlife Resources. and Utah State University Extension Service were involved in various aspects of planning. implementation, and follow-up management of the prescribed burns.

\section{Description}

Park Valley

Park Valley Hereford Corporation, located north of Park Valley in 
the northwest corner of Utah, was selected as the first Demonstration Ranch. The improvements were conducted on a broad, gently sloping alluvial flat at the base of the Raft River Mountains. The area had a long history of heavy grazing and was in poor condition. The range site was a semidesert shallow hardpan $(40 \%)$ semidesert stony loam $(60 \%)$ complex. Soils were a greyish-brown clay loam with a large percentage of fractured rock of granitic origin throughout the horizons. A hardpan existed about $30.5 \mathrm{~cm}$ (12 inches) in depth on the semidesert shallow hardpan site. Black sagebrush (Artemisia arbuscula) dominated this site with small amounts of bluebunch wheatgrass (Agropyron spicatum) and sandberg bluegrass (Poa secunda). Soil on the stony loam site was moderately deep $(25-61 \mathrm{~cm})$, and big sagebrush dominated with very little understory vegetation. Precipitation averaged $305 \mathrm{~mm}$ (12 inches) with $60 \%$ falling in the winter months. Elevation of the site was $1,646 \mathrm{~m}(5,400$ feet $)$. Toward the base of the mountain, juniper dominated the site but decreased as it spread into the sagcbrush community on the alluvial flat.

A lightning-caused fire burned 73 ha (180 acres) of sagebrush and juniper in the west pasture in 1971. Crested wheatgrass was drilled into the ashes and a good stand was established. These results demonstrated the site potential and were instrumental in gaining agency and rancher approval to burn other suitable areas.

The first prescribed burn was conducted in September of 1974 within the west pasture. Three hundred and sixty-five hectares (880 acres) were actually burned and drilled to crested wheatgrass at the rate of $2.72 \mathrm{~kg}(6 \mathrm{lb})$ per acre. The second burn was conducted in August of 1976 within the middle pasture. Five hundred and sixteen hectares (1.275 acres) were burned and drilled to crested wheatgrass (Agropyron desertorum), alfalfa (Medicago sativa), and yellow sweet clover (Melilotus officinalis) at a rate of $2.72,1.12,1.12 \mathrm{~kg}$ per hectare $(6,1,1 \mathrm{lb} /$ acre $)$, respectively. Four $30.5-\mathrm{m}$ permanent line transects were installed in key areas on the semidesert stony loam site in each pasture prior to treatment to measure the percentage change in vegetative cover. Two $30.5-\mathrm{m}$ permanent line transects were installed on the wildfire seeding to determine vegetative cover and measure the improvement that resulted from 2 years rest from grazing. Annual forage production was determined by the SCS ocular estimate in the west pasture prior to the burn in 1974 and by clipping a series of $193-\mathrm{m}^{2}\left(9.6 \mathrm{ft}^{2}\right)$ plots in subsequent years (1975-1977). Clippings were taken on the middle pasture in 1975 and 1976 prior to burning and in 1977, the first year after treatment.

The fire did not burn thick, mature stands of juniper. Sufficient understory vegetation to carry the fire was not present and the winds were light and would not sustain a crown fire. To finish treating the area, 356 ha ( 800 acres) of juniper were double chained in the winter of 1976. Crested wheatgrass, alfalfa, and yellow sweet clover were aerially broadcast on the site between chainings.

\section{Scipio}

Scipio West Bench Grazing Association is located on a gently sloping alluvial tlat at the base of the Canyon Mountains about $6.4 \mathrm{~km}$ (t miles) west of Scipio in central Utah. The range site was an upland stony loam in poor condition with a uniform stand of dense big sagebrush and very little understory vegetation. The elevation ranged between 1,890-2,073 m (6,2000-6,800 feet). Precipitation averaged $+10 \mathrm{~cm}$ ( 16 inches) with $20-45 \%$ falling during the growing season. The soils were deep and well drained. The surface layers were dark grayish-brown loam between $15-25 \mathrm{~cm}(6-10$ inches) thick with a high percent of cobbles. The surface soils were moderately tiltired with cobbly and coarse fragments increasing with depth.

the area was split into four 324-ha (800 acre) pastures, and a

$5-1$; permanent line transect was installed in a key area within each pasture to determine percent change in vegetative cover. Three pastures were burned in July and August of 1976. Cool, humid weather terminated burning before all pastures were treated. The remaining pasture was dot le-chained with a modified Ely chain. The treated areas were aerially seeded to crested wheatgrass, intermediate wheatgrass (Agropyron intermedium), and yellow sweet clover and then covered with a chain.

\section{Mountain}

Diamond Mountain is located $40 \mathrm{~km}$ (25 miles) northeast of Vernal, Utah. Two neighboring ranchers conducted small prescribed burns in August 1976. The range site was mountain loam in fair condition with a dense stand of big sagebrush and a fair understory of perennial grasses and forbs. Elevation was about 2,500 $\mathrm{m}(8,200$ feet) and precipitation averaged $51.0 \mathrm{~cm}$ (20 inches) with about $60 \%$ falling during the growing season. Soils are deep and well drained. The surfacc layers were a dark brown loam with clay loam subsurface layers.

To determine percent change in vegetative cover, a 30.5-m permanent line transect was installed in Walker pasture and two 100-toepace transects were taken before and after the Calder burn. Forage production prior to, and 1 year following both burns was determined by clipping a series of $2.93 \mathrm{~m}^{2}$ plots within each pasture. The Calder burn was drilled to crested wheatgrass, Russian wildrye (Elymus junceus), alfalfa, and yellow sweet clover. The Walker burn was not seeded.

\section{Altamont}

The Myrin burn was conducted on a sandy river bottom $11 \mathrm{~km}$ (7 miles) southwest of Altamont in the Unita Basin in August of 1976. The big sagebrush was $1.2-2.1 \mathrm{~m}(4-7 \mathrm{feet})$ tall with no understory vegetation. Burning conditions were marginal and $1 / 3$ of the area was left unburned. The unburned area was plowed with a rototiller and the entire area was drilled to crested wheatgrass, Russian wildrye, alfalfa, and yellow sweet clover at $4.48,1.2,1.2,1.2 \mathrm{~km}$ per hectare, respectively. No pre- or post-treatment measurements were taken on this project.

\section{Burning Prescriptions}

The planned burning prescriptions for all six burns were similar: temperatures greater than $41.67^{\circ} \mathrm{C}\left(75^{\circ} \mathrm{F}\right)$, relative humidity $15-20 \%$, and winds steady at $8-16 \mathrm{~km}$ per hour $(5-10 \mathrm{mph})$. These conditions were necessary to get a large broadcast burn on the extensive acreages involved. Other prescribed burn preparations were outlined and followed (Ralphs et al. 1975).

Treatment costs were obtained from the ranchers, and the average cost of prescribed burning and associated improvements was determined. An economic analysis of the 1974 Park Valley west pasture project was conducted to determine the profitability of burning and seeding. An AUM was assumed equal to $1000 \mathrm{lb}$ of forage and valued at $\$ 5$. Proper use was $65 \%$, and the lifetime of the seeding was assumed to be 20 years.

\section{Results}

\section{Park Valley}

Sagebrush was essentially eliminated on the areas within the fire guards that actually burned. Due to the release of native grasses and seeded species, grass and legume cover increased an average of $350 \%$ (Table 1). On a similar site in southern Idaho which had a good stand of understory grasses and forbs prior to burning, grass cover increased $90 \%$ after 4 years (Blaisdell $1953)$.

There were no pretreatment cover measurements for the 1971 wildlife and seeding but transects installed in 1974 and read in 1975 and 1977 revealed that the grass cover increased from $+.5 \%$ to $16 \%$ as a result of a 2-year rest. This attests to the benefits of periodic rest of heavily used seeded spring range.

Forage production increased from $112 \mathrm{~kg} /$ hectare (100 $\mathrm{lb} / \mathrm{acre})$ to an average of $703 \mathrm{~kg} /$ hectare $(628 \mathrm{lb} / \mathrm{acre})$ in the west pasture. The middle pasture forage incresed from $84 \mathrm{~kg} /$ hectare $(75 \mathrm{lb} /$ acre $)$ to $521 \mathrm{~kg} /$ hectare $(465 \mathrm{lb} /$ acre $)$ in the first year following the burn. There was essentially no forage production under the juniper stand prior to chaining, but forage production the fïst year after treatment was $157 \mathrm{~kg} /$ hectare $(140 \mathrm{lb} / \mathrm{acre})$. The 3-year average forage production on the wildfire seeding was $1,008 \mathrm{~kg} /$ hectare $(900 \mathrm{lb} / \mathrm{acre})$. On a slightly more favorable site in Central Utah, Cook (1966) obtained an average yield 
Table 1. Range site, condition, vegetative cover, and forage production of prescribed burns and associated range improvements.

\begin{tabular}{|c|c|c|c|c|c|c|c|c|c|c|c|c|c|c|c|c|}
\hline \multirow{2}{*}{$\begin{array}{l}\text { Location } \\
\text { Project } \\
\text { Year }\end{array}$} & \multicolumn{8}{|c|}{ Park Valley } & \multicolumn{4}{|c|}{ Scipio } & \multicolumn{4}{|c|}{ Diamond Mountain } \\
\hline & \multicolumn{3}{|c|}{$\begin{array}{c}\text { Wildfire } \\
1971\end{array}$} & \multicolumn{2}{|c|}{$\begin{array}{l}\text { West pasture } \\
\text { burn } 1974\end{array}$} & \multicolumn{2}{|c|}{$\begin{array}{l}\text { Middle pasture } \\
\text { burn } 1976\end{array}$} & $\begin{array}{c}\text { Chaining } \\
1976\end{array}$ & \multicolumn{2}{|c|}{$\begin{array}{l}\text { Burn } \\
1976\end{array}$} & \multicolumn{2}{|c|}{$\begin{array}{c}\text { Chaining } \\
1976\end{array}$} & \multicolumn{2}{|c|}{$\begin{array}{l}\text { Walker } \\
\text { burn } 1976\end{array}$} & \multicolumn{2}{|c|}{$\begin{array}{c}\text { Calder } \\
\text { burn } 1976\end{array}$} \\
\hline Range site & \multicolumn{3}{|c|}{$\begin{array}{l}\text { Semidesert } \\
\text { stony loam }\end{array}$} & \multicolumn{2}{|c|}{$\begin{array}{l}\text { Semidesert } \\
\text { stony loam }\end{array}$} & \multicolumn{2}{|c|}{$\begin{array}{l}\text { Semidesert } \\
\text { stony loam }\end{array}$} & $\begin{array}{l}\text { Upland stony } \\
\text { hills-juniper }\end{array}$ & \multicolumn{2}{|c|}{$\begin{array}{l}\text { Upland } \\
\text { stony loam }\end{array}$} & \multicolumn{2}{|c|}{$\begin{array}{l}\text { Upland } \\
\text { stony loam }\end{array}$} & \multicolumn{2}{|c|}{$\begin{array}{l}\text { Mountain } \\
\text { loam }\end{array}$} & \multicolumn{2}{|c|}{$\begin{array}{l}\text { Mountain } \\
\text { loam }\end{array}$} \\
\hline Range condition & 1974 & 1975 & 1977 & $\begin{array}{r}\text { Pc } \\
\text { Before }\end{array}$ & oor & $\begin{array}{r}\mathrm{F} \\
\text { Befor }\end{array}$ & $\begin{array}{l}\text { Poor } \\
\text { e After B }\end{array}$ & $\begin{array}{c}\text { Poor } \\
\text { Before After }\end{array}$ & Befor & $\begin{array}{l}\text { Poor } \\
\text { e After }\end{array}$ & $\begin{array}{r}P \\
\text { Before }\end{array}$ & oor & Befo & $\begin{array}{l}\text { Fair } \\
\text { e After }\end{array}$ & Befo & e After \\
\hline Sagebrush & 0 & 0 & 0 & 25 & $2 *$ & 28 & $.3 *$ & & 22 & $0 *$ & 24.4 & 10.5 & 22 & 0 & 30 & 1 \\
\hline Other shrubs & 1 & 2 & 6 & 4 & 2.5 & 15 & 4 & & 8.2 & 1.1 & .25 & .5 & 0 & 1 & 3 & 2 \\
\hline Grass and legume & 4.5 & 7.5 & $16^{*}$ & 4 & $13^{*}$ & 3 & 17.5 & & 6 & 3 & 2.4 & 3.4 & 23 & 16 & 17 & 28 \\
\hline Forbs & 6.5 & 9 & .5 & 2.5 & $9.8^{*}$ & 5.5 & 5.3 & & .4 & 5.3 & 0 & 2.2 & 11 & 1 & + & 5 \\
\hline $\begin{array}{l}\text { Forage production } \\
\qquad(\mathrm{kg} / \mathrm{ha})\end{array}$ & & ${ }^{a} 1008$ & & 112 & ${ }^{a} 703 *$ & 84 & ${ }^{b} 521 * 0$ & ${ }^{b} 157$ & & & & & 258 & ${ }^{b} 287$ & 370 & ${ }^{b} 411$ \\
\hline
\end{tabular}

Statistically signiticant ( $P<.(15)$.

Alerage forage production 1975-1977.

Forage production first year atter treatment.

of $1.286 \mathrm{~kg} /$ hectare $(1,148 \mathrm{lb} / \mathrm{acre})$ from seeded crested wheatgrass.

\section{Scipio}

A very hot and intense fire resulted from extremely dry conditions and low humidities on the Scipio burn. Big sagebrush was entirely eliminated from all of the area that burned. The area was seeded, but the 1976-1977 drought was especially severe in central Utah, thus preventing establishment of the seeded species. Only $127 \mathrm{~mm}$ (5 inches) of precipitation fell between May of 1976 and August 1977, compared to the water year average of $410 \mathrm{~mm}$ ( 16 inches).

Sagebrush cover in the chained pasture declined from $24 \%$ to $10 \%$. Due to lack of competition from native perennial grasses and failure of seeded grasses, the remaining sagebrush is expected to increase in vigor and regain dominance of the site.

\section{Diamond Mountain}

Approximately $80 \%$ of the area within the two Diamond Mountain projects actually burned. Some of the less dense stands of sagebrush did not burn and created a mosaic burn pattern. The resulting diversity of vegetation enhanced the aesthetic and wildiife values of the site. The remaining sagebrush also functioned as wind breaks and drifting soil and ash was deposited in and around these islands.

The Walker burn was the only one not followed by seeding. Grass cover decreased from 23\% to $16 \%$. Perchanec et al (1954) also reported a decline in grass cover in the first 2 years following the burn, but it increased $60 \%$ by the end of 12 years. An almost pure grass stand, dominated by western wheatgrass (Agropyron smithii), remained and is expected to fill in and increse in density and cover in subsequent years.

The Calder site was drilled but seedling emergence was spotty. On the open ridges where there was little competition from native grasses, seeded species became established. However. in the swales, competition from native grasses prevented seeded species from becoming established. The combined eflect of seeded species and increased native grasses improved the grass and legume cover from $17 \%$ to $28 \%$. There was little increase in forage production the first year after treatment, but production is expected to increase as the grass stand matures.

\section{Costs}

Burning costs were separated into two categories: cash costs or actual expenditures by ranchers; and noncash costs, which included all of the donated equipment, manpower, and rancher's labor. The average cash cost of the prescribed burns was $\$ 2.97 /$ hectare (\$1.20/acre). The major component was fire line construction. Existing roads and natural fuel breaks were used as much as possible but some lines had to be constructed. The average cost was $\$ 2.69 /$ hectare $(\$ 1.09 /$ acre) or $\$ 88 /$ kilometer $(\$ 1+2 / \mathrm{mile})$ of line constructed. Other cash cost included fuel for ignition and miscellaneous labor expenses.

Labor was the largest component of the noncash costs averaging 5.07/hectare $(\$ 2.05 /$ acre $)$. Equipment costs were $\$ 3.63 /$ hectare $(\$ 1.47 / \mathrm{acre})$. The total cost, including both cash and noncash costs, was $\$ 11.32 /$ hectare $(\$ 4.58 /$ acre). This approximates Nielsen and Hinkley's (1975) estimate of \$9.88/hectare $(\$ 4.00 /$ acre $)$, and is substantially lower than spraying, plowing, rotobeating, or chaining sagebrush.

All but one of the projects was seeded following the burn. Rangeland drills were used on four of the projects and acquired through cooperative agreements between the Soil Conservation Districts and the Forest Service or BLM. There were no rental costs for the drills, but parts and repairs were included in the seeding costs. The average cost of seed and drilling was $\$ 17.79 /$ hectare $(\$ 7.20 /$ acre). On the Scipio burn, the seed was aerially broadcast and then covered with a chain for $\$ 24.71$ hectare $(\$ 10 /$ acre $)$.

The costs of additional treatments to complete renovation of the pastures were considerably greater than burning. The cost of double chaining juniper and seeding to crested wheatgrass, alfalfa, and clover on the Park Valley project was $\$ 44.62 /$ hectare (\$18.06/acre). Double chaining sagebrush with an Ely chain and seeding on the Scipio project was $\$ 33.88$ /hectare (\$13.71/acre). Rototilling sagebrush on the Altamont project cost $\$ 24.71 /$ hectare $(\$ 10 /$ acre $)$.

An economic analysis of the Park Valley west pasture development, including the burn, seeding, fence, and water developments, gave an internal rate of return of $8 \%$. The fencing was completed prior to the burns, and the water developments would have been installed had the burn not taken place. Without these additional improvements, the internal rate of return for the burning and seeding alone would have been $17 \%$.

\section{Problems Encountered}

Weather conditions determine the behavior of a fire and consequently the effectiveness of a burn. The range of condi- 
tions necessary to obtain a good burn yet maintain safety margins are very narrow. Temperatures must be high enough to lower the mid-day humidity below $20 \%$. Experience for these burns showed that the dampening effect at higher humidities prevented fire from spreading. However, in gullies and draws supporting dense stands of big sagebrush, sufficient heat was generated to preheat forward vegetation and overcome the suppressive effect of higher humidities. Conversely, humidities below $15 \%$ make vegetation very explosive and greatly increase the risk of a fire escaping.

A steady breeze is also necessary to carry a fire throughout the burning unit. Variable winds cause a fire to lose momentum, resulting in a patchy, nonuniform burn. On the other hand, whirlwinds or strong gusts can easily carry burning debris across the line and start a fire outside the burning unit. Unpredictable and inconsistent weather conditions increase burning hazards and raise manpower and equipment demands.

Wind erosion was another factor that caused severe problems in a nearby community. Blowing dust and ash annoyed residents close to the burn. However, where seedings were successful, wind erosion and blowing dust ceased after the first year. Pechanec et al. (1954) was in agreement that accelerated erosion was arrested 2 years after the burn.

The biggest risk encountered was that of fire jumping the line and escaping. There was not one burn that the fire did not jump at least once. Fortunately, most of the spot fires were contained before they escaped. One did get away and burned additional private, BLM, and Forest Service land and ranchers were faced with a large suppression bill.

\section{Literature Cited}

Aro, R.S. 1971. Evaluation of pinyon-juniper conversion to grassland. J. Range Manage 24:188-197.

Blackburn, W.H., and P.T. Tueller. 1970. Pinyon-juniper invasion in black sagebrush communities in east-central Nevada. Ecology 51:841-848.

Blaisdell, J.P. 1953. Ecological effects of planned burning of sagebrushgrass range on the upper Snake River plains. U.S.D.A. Tech. Bull. No. 1075. $39 \mathrm{p}$.

Britton, C.H., and M.H. Ralphs. 1978. Use of fire as a management tool in sagebrush ecosystems. Proceedings, Sagebrush Symposium. Utah State Univ. Logan, Utah. April 27-28, 1978.

Burkhardt, W.J., and E.W. Tisdale. 1969. Nature and successional status of western juniper vegetation in Idaho. J. Range Manage. 22:264-270.
Conrad, C.E., and C.E. Poulton. 1966. Effect of a wildfire on Idaho fescue and bluebunch wheatgrass. J. Range Manage. 19:138-141.

Cook, C. Wayne. 1966. Development and use of foothill ranges in Utah. Utah Agr. Exp. Sta. Bull. 47 p.

Cottam, W.B. 1947. Is Utah Sahara bound? Univ. of Utah Ext. Bull. Vol. 37. No. 11.40 p.

Daubenmire, R. 1968. Ecology of fire in grasslands. Advanced Ecological Research V. p. 209-266.

McCulloch, C.Y. 1969. Some effects of wildfire on deer habitat in pinyonjuniper woodland. J. Wildlife Manage. 33:778.784.

Miller, H.A. 1963. Use of fire in wildlife management. Tall Timber Fire Ecology Conf. Proc. 2:19-30.

Nielsen, D.D. and S.D. Hinkley. 1975. Economic and environmental impacts of sagebrush control on Utah's rangelands-review and analysis. Utah Agr. Exp. Sta. Res. Rep. No. 25. 27 p.

Pechanec, J.F., G. Stewart, and J.P. Blaisdell. 1954. Sagebrush burning good. good and bad. Farmers Bull. 1948. 34 p.

Pickford, G.D. 1932. The influence of continued heavy grazing and promiscuous burning on spring-fall ranges in Utah. Ecology 18:159-171.

Plummer, A.P. 1958. Restoration of juniper pinyon ranges in Utah. Proc. Soc. Amer. Foresters. 1958. p. 207-211.

Ralphs, M.H., D. Schen, and F.E. Busby. 1975. Prescribed burningeffective control of sagebrush and open juniper. Utah Sci. 26:94-98.

Tueller, P.T. 1973. Secondary succession, disclimax and range condition standards in desert shrub vegetation. In: D. N. Hyder (ed.) Arid ShrublandsProceedings of the third workshop of the US/Australia Rangelands Panel. Tucson, Arizona, March 26-April 5, 1973.

Uresk, D.W., J.F. Cline, and W.H. Rickard. 1976. The impact of wildlife on three perennial grasses in south-central Washington. J. Range Manage 29:309.310.

Warskow, W.L. 1977. Fire water. Address to Joint Meeting of the Rocky Mountain Fire Council and the Intermountain Forest Fire Research Council. Casper, Wyoming, Nov. 2, 1977.

West, N.E., K.H. Rea, and R.J. Tausch. 1975. Basic synecological relationships in juniper-pinyon woodland. In: The Pinyon-Juniper Ecosystem: A Symposium. Utah State Univ. Logan, Utah. May 1975. p. 41-53.

Wright, H.A. 1971. Why squirreltail is more tolerant to burning than needleandthread. J. Range Manage. 24:277-284.

Wright, H.A 1972. Shrub response to fire. In: McKell, Blaisdell, and Gooding (ed.) Wildland Shrubs-Their Biology and Utilization. U.S.D.A. F.S. Gen. Tech. Rep. INT-1. +94 p.

Wright, H.A 1974. Range burning. J. Range Manage 27:5-11

Wright, H.A., A.M. Churchill, and U.S. Stevens. 1976. Effect of prescribed burning on sediment, water yield, and water quality from dozed juniper lands in central Texas. J. Range Manage 29:294-298.

Wright, H.A. 1977. Northern Desert Shrubs-grassland: a review of fire literature and state of the art. Cold Desert Fire Management Workshop. Boise Interagency Fire Center. May 2-5, 1977.

Research Assistant Wanted: Available immediately. Located at Sonora Research Station. Pay \$550. per mo.. house provided-Grazing management and range animal nutrition-prefer $\mathrm{PhD}$ candidate. For details contact: Dr. M.M. Kothmann. Dept. Range Science, Texas A\&M University, College Station, TX $77.43 .(713), 145-7331$ 